LOSARI: Jurnal Pengabdian Kepada Masyarakat

http://ojs.losari.or.id/index.php/losari

Volume 2 | Nomor 1 | Juni | 2020

e-ISSN: 2684-8678 dan p-ISSN: 2684-9887

\title{
Sosialisasi Nilai-nilai Dasar Anti Korupsi kepada Mahasiswa Fakultas Teknik Universitas Muhammadiyah Jakarta
}

\section{Liza Nazifah ${ }^{1}$}

\begin{tabular}{l}
\hline Keywords : \\
Korupsi; \\
Sosialisasi; \\
Mahasiswa. \\
Corespondensi Author \\
${ }^{1}$ Badan Pengembangan Sumber Daya \\
Manusia (BPSDM) Provinsi DKI \\
Jakarta \\
Email: lisa.nazifah@gmail.com
\end{tabular}

Keywords :

Korupsi;

Sosialisasi;

Corespondensi Author

Badan Pengembangan Sumber Day

Jakarta

Email: lisa.nazifah@gmail.com

\begin{abstract}
Abstrak. Korupsi merupakan akar dari banyak persoalan besar di negeri ini. Merusak segala sendi kehidupan mulai dari ekonomi, politik, sosial, demokrasi hingga menyentuh kebutuhan dasar manusia seperti pendidikan dan kesehatan. Mahasiswa sebagai generasi muda yang enerjik harus mulai aktif diberdayakan dalam aksi pemberantasan korupsi di Indonesia, mulai dari hal yang sederhana yaitu pembentukan karakter yang berintegritas agar mampu menerapkan nilainilai dasar anti korupsi. Bentuk kegiatan berupa sosialisasi kepada mahasiswa Fakultas Teknik Universitas Muhammadiyah Jakarta melalui paparan materi, diskusi dan tanya jawab serta role play. Tujuan dilakukannya kegiatan ini adalah untuk membekali mahasiswa dengan pemahaman tentang nilai-nilai dasar anti korupsi dan menerapkannya dalam kehidupan sehari-hari sehingga dapat menginisiasi terbentuknya kepribadian anti korupsi pada mahasiswa. Melalui kegiatan ini, mahasiswa menyadari bahwa korupsi milyaran dimulai dari kecurangan-kecurangan kecil dalam kehidupan sehari-hari yang lama kelamaan menjadi sebuah kebiasaan. Kegiatan ini mendapatkan respon yang positif dari para peserta yang terlihat dari antusiasme dan peran aktif mereka selama sosialisasi berlangsung hingga selesai.
\end{abstract}

\section{Pendahuluan}

Korupsi yang terjadi di Indonesia sudah sampai kepada taraf yang mengkhawatirkan karena dampak yang ditimbulkan oleh korupsi sangat massif dan menjangkau semua aspek kehidupan masyarakat. Korupsi telah menghancurkan perekonomian, demokrasi, politik, hukum, sistem pemerintahan, dan sosial kemasyarakatan di negeri ini. Tidak hanya menyebabkan kerugian keuangan negara, korupsi juga berdampak kepada pendapatan negara per kapita, tingkat pengangguran, tingkat pendidikan, tingkat kriminalitas, hingga kepada banjir dan kebakaran hutan. Pemberitaan tentang tindak pidana korupsi pun kerap menyemarakkan pemberitaan nasional dan internasional, baik di media cetak maupun media elektronik.
Korupsi merupakan kejahatan yang luar biasa (extraordinary crime) sehingga upaya pencegahan dan pemberantasannya pun harus luar biasa. Namun beragam upaya yang telah dilakukan sepertinya belum memberikan dampak yang signifikan seiring dengan masih maraknya kejadian korupsi di tanah air. Korupsi pun seakan-akan telah menjadi bagian dari kehidupan kita sehingga korupsi tidak lagi dianggap sebagai sesuatu yang harus dibasmi. Jika kondisi ini tetap dibiarkan berlangsung, maka cepat atau lambat korupsi akan menghancurkan negeri ini.

Berdasarkan Undang-undang Nomor 31 Tahun 1999 j.o Undang-undang Nomor 20 Tahun 2001 tentang Pemberantasan Tindak Pidana Korupsi (UU PTPK), selain menjadi tanggung jawab dan kewenangan Pemerintah 
dan penegak hukum, pemberantasan korupsi sangat membutuhkan peran serta masyarakat dalam mencegah dan mengungkap tindak pidana korupsi yang terjadi di sekitar kita. Oleh karena itu sebagai generasi muda penerus bangsa, mahasiswa merupakan salah satu bagian penting dari masyarakat yang dapat terlibat aktif dalam upaya pemberantasan korupsi di Indonesia (Indonesia, 2001).

Peran aktif mahasiswa diharapkan lebih difokuskan pada upaya pencegahan korupsi dengan ikut membangun budaya anti korupsi dalam masyarakat. Mahasiswa dengan jiwa dan semangat mudanya dapat berperan sebagai motor penggerak sikap anti korupsi di masyarakat. Untuk dapat berperan aktif, mahasiswa butuh pemahaman yang lebih dalam mengenai korupsi dan strategi pemberantasannya. Diawali dengan menerapkan nilai-nilai dasar anti korupsi sebagai perilaku teladan dalam kehidupan sehari-hari (Korupsi, 2011)

Pemerintah kini sangat gencar mensosialisasikan pendidikan karakter. Bahkan Kementrian Pendidikan Nasional sudah mencanangkan pendidikan karakter untuk semua tingkat pendidikan mulai dari pendidikan dasar sampai perguruan tinggi dengan mencanangkan empat nilai karakter utama yang menjadi ujung tombak penerapan karakter di kalangan peserta didik, yakni jujur (dari olah hati), cerdas (dari olah pikir), tangguh (dari olah raga), dan peduli (dari olah rasa dan karsa) (Muchtar \& Suryani, 2019).

Pendidikan karakter tidak hanya butuh disosialisasikan, namun lebih dari itu juga butuh diinternalisasikan sejak dini di semua level pendidikan. Lembaga pendidikan harus tampil menjadi pionir pendidikan karakter karena peran strategis pendidikan dalam mempersiapkan dan membentuk kader masa depan yang berkualitas di bidang ilmu juga moral. Lembaga pendidikan harus bekerja sama dengan keluarga, masyarakat, dan elemen lain untuk mewujudkan agenda besar penanaman karakter yang kuat kepada peserta didik (Sumaryati, 2015).

Pendidikan karakter tersebut juga diterapkan dalam Pendidikan Anti Korupsi. Hal ini merupakan salah satu upaya reformasi melalui sistem pendidikan untuk melakukan terobosan yang berkelanjutan, termasuk untuk mendorong terciptanya good cooperate culture di sekolah dan perguruan tinggi. Perguruan tinggi dapat menjalankan peran strategis dalam pendidikan anti korupsi terutama dalam menerapkan perilaku yang menganut nilai-nilai dasar anti korupsi kepada mahasiswa. Melalui pendidikan anti korupsi di lingkungan sekolah dan kampus, diharapkan siswa dan mahasiswa memiliki modal sosial untuk membiasakan berperilaku anti korupsi dalam hal sekecil apapun agar terbangun karakter anti korupsi (Kristiono, 2018). Menyadari bahwa masih langkanya lingkungan yang anti korupsi, maka pengaruh faktor eksternal yang berasal dari lingkungan harus diminimalisir semaksimal mungkin (Nazifah, 2019).

Pendidikan diyakini merupakan kunci masa depan bangsa dan pendidikan anti korupsi merupakan pendidikan seumur hidup yang sangat esensial ditanamkan sedini mungkin. Kualitas sumber daya manusia merupakan modal utama pembangunan bangsa. Penanaman karakter menjadi salah satu prasyarat keberhasilan pengembangan sumber daya manusia di Indonesia. Kampus sebagai sarana pencetak generasi bangsa dengan taraf yang lebih tinggi juga sangat peduli terhadap pendidikan anti korupsi (Suryani, 2015)

Dalam upaya pelaksanaan pencegahan dan pemberantasan korupsi sebagaimana diamanatkan dalam Peraturan Presiden Nomor 55 Tahun 2012 tentang Strategi Nasional Pencegahan dan Pemberantasan Korupsi Jangka Panjang Tahun 2012-2025 dan Jangka Menengah Tahun 2012-2014 (Stranas PPK), dan sebagai implementasinya dilakukan penyusunan aksi Pencegahan dan Pemberantasan Korupsi (PPK) setiap tahun yang selanjutnya dikeluarkan Instruksi Presiden Nomor 2 Tahun 2014 tentang Aksi Pencegahan dan Pemberantasan Tindak Pidana Korupsi Tahun 2014, dimana dalam lampiran Inpres tersebut pada bagian ke V diterangkan tentang strategi pendidikan dan budaya anti korupsi yang terdiri atas 22 rencana aksi, dan diantaranya melibatkan lembaga pendidikan tinggi negeri dan swasta dalam pengimplementasiannya (Kadir, 2018).

Nilai-nilai dasar anti korupsi merupakan sikap dasar yang harus dimiliki dan diterapkan oleh setiap individu agar dapat terhindar dari korupsi. Nilai adalah suatu hal yang membutuhkan penghayatan untuk dikehendaki dan tidak dikehendaki serta sangat bermanfaat bagi manusia tentang sesuatu hal yang baik dan buruk, benar dan salah, serta indah dan tidak indah (Taja \& Aziz, 2016).

Terdapat sembilan nilai dasar anti 
korupsi, yaitu jujur, peduli, mandiri, disiplin, tanggungjawab, kerja keras, sederhana, berani dan adil.

1. Jujur

Jujur dapat didefinisikan sebagai lurus hati, tidak berbohong, dan tidak curang. Jujur adalah salah satu sifat yang sangat penting bagi kehidupan mahasiswa, tanpa sifat jujur mahasiswa tidak akan dipercaya dalam kehidupan sosialnya (Sugono, 2008). Individu yang jujur adalah orang yang dapat dipercaya, lurus hati dan tidak berbohong. Kejujuran merupakan modal awal agar dapat dipercaya oleh orang lain. Hal ini merupakan modal awal khususnya bagi mahasiswa agar dapat bekerja sama dengan orang lain dan amanah. Perilaku menyontek, plagiarisme, dan titip absen merupakan manifestasi ketidakjujuran, dapat memunculkan perilaku korupsi. Persoalan ketidakjujuran tersebut merupakan suatu hal yang mengkhawatirkan dan perlu perhatian serius (Taja \& Aziz, 2016).

2. Peduli

Peduli adalah mengindahkan, memperhatikan dan menghiraukan orang lain (Sugono, 2008). Nilai kepedulian sangat penting bagi seorang mahasiswa dalam kehidupan di kampus dan di masyarakat. Sebagai calon pemimpin masa depan, seorang mahasiswa perlu memiliki rasa kepedulian terhadap lingkungannya, baik di dalam kampus maupun di luar kampus.

3. Mandiri

Mandiri adalah dapat berdiri sendiri tanpa bantuan orang lain. Mandiri juga berarti mampu menemukan solusi dari masalah dan menyelesaikan masalah yang dihadapi. Dengan karakter kemandirian, mahasiswa dituntut untuk mengerjakan semua tanggung jawab dengan usahanya sendiri dan bukan orang lain (Supardi, 2004). Misalnya dalam menyusun tugas dan skripsi.

4. Disiplin

Menurut Sugono definisi kata disiplin adalah ketaatan (kepatuhan) kepada peraturan (Sugono, 2008). Disiplin berarti kebiasaan atau tindakan yang konsisten terhadap aturan yang ada. Dalam kehidupan kampus baik akademik maupun sosial, penting bagi mahasiswa untuk hidup disiplin agar terbiasa dengan aturan yang berlaku sehingga terbawa hingga ke dunia kerja dan persaingan global.

5. Tanggungjawab

Menurut Sugono definisi tanggung jawab adalah keadaan wajib menanggung segala sesuatunya (jika dituntut, dipersalahkan dan diperkarakan) (Sugono, 2008). Tanggung jawab merupakan sikap dan perilaku dalam melaksanakan tugas baik yang berkaitan dengan diri sendiri maupun orang lain. Sikap tanggung jawab bukan hanya nilai dasar anti korupsi, namun juga nilai dasar daam kepemimpinan yang penting untuk mahasiswa untuk perkembangan karirnya di kemudian hari.

6. Kerja keras

Bekerja keras didasari dengan adanya kemauan. Kata "kemauan" menimbulkan asosiasi dengan ketekadan, ketekunan, daya tahan, tujuan jelas, daya kerja, pendirian, pengendalian diri, keberanian, ketabahan, keteguhan, tenaga, kekuatan, kelaki-lakian dan pantang mundur. Adalah penting sekali bahwa kemauan mahasiswa harus berkembang ke taraf yang lebih tinggi karena harus menguasai diri sepenuhnya lebih dulu untuk bisa menguasai orang lain.

7. Sederhana

Dengan menerapkan prinsip hidup sederhana, mahasiswa dibina untuk memprioritaskan kebutuhan di atas keinginannya. Prinsip hidup sederhana ini merupakan parameter penting dalam menjalin hubungan antara sesama mahasiswa karena prinsip ini akan mengatasi permasalahan kesenjangan sosial, iri, dengki, tamak, egois, dan yang sikap-sikap negatif lainnya lainnya. Prinsip hidup sederhana juga menghindari seseorang dari keinginan yang berlebihan (Korupsi, 2011).

8. Berani

Berani adalah hati yang mantap dan rasa percaya diri yang besar dalam menghadapi ancaman atau kesulitan lainnya. Berani artinya tidak takut ataupu gentar. Untuk mengembangkan sikap keberanian demi mempertahankan pendirian dan keyakinan mahasiswa, 
terutama sekali mahasiswa harus mempertimbangkan berbagai masalah dengan sebaik-baiknya (Korupsi, 2011).

9. Adil

Berdasarkan arti katanya, adil adalah sama berat, tidak berat sebelah, tidak memihak. Adil juga berarti perlakuan yang sama tanpa membeda-bedakan golongan tertentu. Bagi mahasiswa karakter adil ini perlu sekali dibina sejak masa perkuliahannya agar mahasiswa dapat belajar mempertimbangkan dan mengambil keputusan secara adil dan benar.

Korupsi terjadi ketika tidak ada nilia-nilai anti korupsi yang ditanamkan dalam diri. Melalui pembiasaan dan pengembangan nilainilai dasar anti korupsi, diharapkan setiap individu memiliki kendali diri terhadap pengaruh buruk dari lingkungan sekitarnya sehingga korupsi dapat dicegah.

Tujuan dilakukannya kegiatan sosialisasi anti korupsi pada mahasiswa adalah untuk membekali mahasiswa dengan pemahaman nilai-nilai dasar anti korupsi dan menerapkannya dalam kehidupan sehari-hari sehingga dapat menginisiasi terbentuknya kepribadian anti korupsi pada mahasiswa sebagai penerus bangsa. Dengan melakukan sosialisasi secara berkesinambungan kepada mahasiswa, maka diharapkan ke depannya mahasiswa dapat menjadi agent of change di lingkungannya masing-masing.

\section{Metode}

Kegiatan ini dilakukan pada sebagai rangkaian kegiatan penyuluhan anti korupsi kepada masyarakat, khususnya di bidang pendidikan. Bentuk kegiatan berupa sosialisasi nilai-nilai dasar anti korupsi kepada mahasiswa Teknik Kimia Universitas Muhammadiyah Jakarta semester akhir, yang dalam jangka waktu dekat akan meninggalkan bangku kuliah dan siap mengaplikasikan ilmunya di tengah masyarakat, baik dengan bekerja maupun berwirausaha.

Sosialisasi diawali dengan menyampaikan paparan singkat tentang materi anti korupsi berdasarkan UU PTPK diikuti dengan sesi tanya jawab terkait materi yang diberikan. Dilanjutkan dengan menonton film singkat tentang perilaku koruptif, lalu peserta sosialisasi dibagi dalam kelompok-kelompok untuk tugas bermain peran atau role play.
Role play merupakan salah satu pembelajaran berdasarkan pengalaman yang menyenangkan melalui pengembangan imajinasi dan penghayatan peserta didik. Metode bermain peran atau role playing adalah salah satu proses belajar yang tergolong dalam metode simulasi (Brataningrum, Novianto, \& Sarjana, 2018)

Metode role playing (bermain peran) juga dapat diartikan sebagai suatu cara penguasaan materi melalui pengembangan dan penghayatan peserta didik. Pengembangan imajinasi dan penghayatan dilakukan oleh peserta didik dengan memerankannya sebagai tokoh hidup atau benda mati. Dengan kegiatan memerankan ini akan membuat peserta didik lebih meresapi perolehannya.

Beberapa hal yang perlu diperhatikan dalam pelaksanaan metode bermain peran ini adalah penentuan topik, penentuan anggota pemeran, pembuatan naskah, latihan singkat dialog dan pelaksanaan permainan peran.

\section{Hasil dan Pembahasan}

Tahapan-tahapan pelaksanaan kegiatan sosialisasi ini adalah sebagai berikut:

1. Tahap Perencanaan

Kegiatan perencanaan dimulai dengan melakukan koordinasi dengan Dekan Fakultas Teknik Universitas Muhammadiyah Jakarta (UMJ). Penulis menyampaikan maksud dan tujuan pelaksanaan sosialisasi serta meminta izin dan arahan lebih lanjut. Berbekal sertifikat kompetensi dari BNSP sebagai Penyuluh Anti Korupsi KPK dan juga sebagai Widyaiswara, pelaksanaan sosialisasi mendapatkan izin dan siap dilaksanakan tanggal 8 Agustus 2019 bertempat di Gedung Fakultas Teknik UMJ, Jl. Cempaka Putih 27 Jakarta Pusat.

2. Tahap Pelaksanaan

Kegiatan dilaksanakan selama 1 hari. Narasumber menyampaikan beberapa pertanyaan awal untuk mengetahui pemahaman dari peserta. Sosialisasi diawali dengan menyampaikan paparan singkat tentang teori anti korupsi, faktor-faktor pencetus terjadinya korupsi, nilai dasar anti korupsi dan jenis-jenis tindak pidana korupsi berdasarkan UU PTPK diikuti dengan sesi tanya jawab terkait materi yang diberikan. Dilanjutkan dengan menonton film singkat tentang perilaku koruptif, lalu peserta sosialisasi dibagi dalam kelompok-kelompok 
untuk menyusun naskah roleplay dan melaksanakan role play di depan kelas. Dalam pelaksanaan role play, kelompok mahasiswa mengambil tema yang familiar dengan kehidupan sehari-hari dan merupakan pengalaman pribadi mereka, seperti kejadian suap karena ditilang oleh polisi lalu lintas, kecurangan saat pengisian bensin di SPBU, pemerasan oleh oknum di terminal dan jalan raya, mencontek dan lain sebagainya. Sebelum kegiatan sosialisasi berakhir, narasumber mengajukan pertanyaan kembali kepada peserta untuk mengetahui tingkat pemahaman peserta mengenai materi yang disampaikan.

\section{Tahap Evaluasi}

Evaluasi dilakukan untuk mengetahui peningkatan pemahaman peserta tentang nilai-nilai dasar anti korupsi dan penerapannya dalam kehidupan sehari-hari. Hal ini dilakukan dengan studi kasus role play dari masing-masing kelompok sehingga dilakukan analisis nilai-nilai dasar anti korupsi yang mana yang dilanggar, dan nilai dasar yang mana yang harus diterapkan atau ditingkatkan. Dengan studi kasus ini, maka mahasiswa semakin memahami manfaat dari nilai dasar anti korupsi dan dampak yang ditimbulkan jika nilai dasar tersebut tidak diterapkan dalam kehidupan sehari-hari.



Foto 1. Sosialisasi nilai dasar anti korupsi

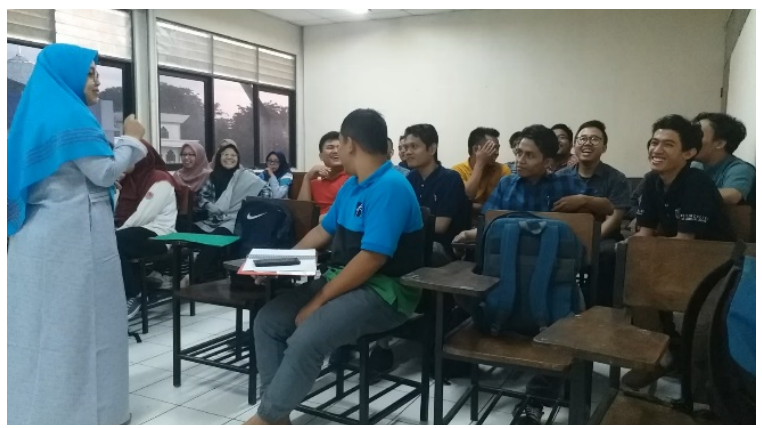

Foto 2. Sesi diskusi dan tanya jawab

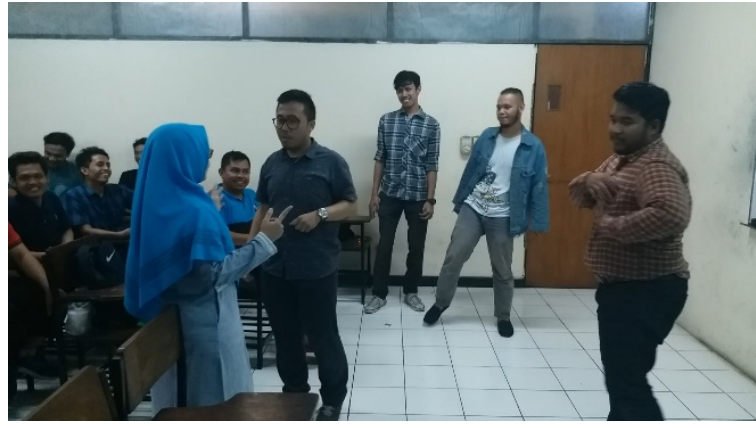

Foto 3. Pengarahan sebelum role play

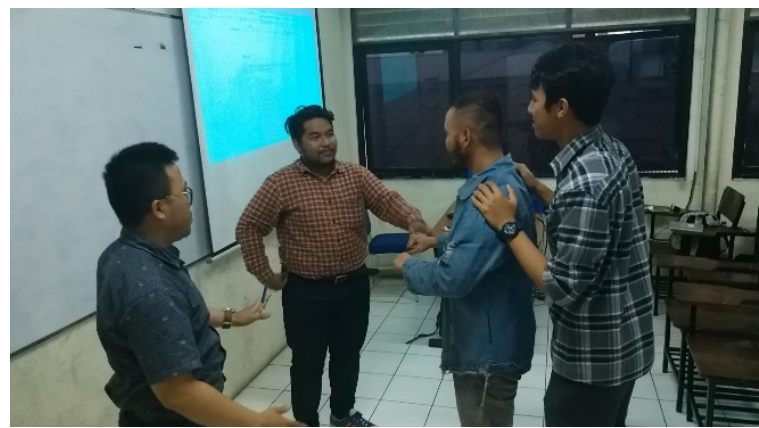

Foto 4. Role play kasus tilang lalu lintas

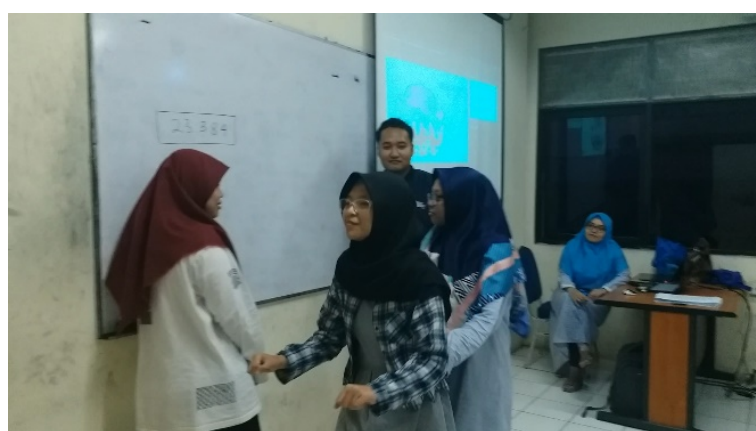

Foto 5. Role play kasus isi bensin di SPBU

\section{Simpulan Dan Saran}

Kegiatan sosialisasi nilai-nilai dasar anti korupsi kepada mahasiswa merupakan salah satu upaya untuk membangkitkan dan menggerakkan generasi muda agar memiliki karakter yang kuat dan berintegritas. Korupsi bukanlah sesuatu yang spontan dilakukan oleh individu dalam skala besar, melainkan dibangun secara perlahan sejak kecil melalui sikap permisif terhadap kecurangan, yang sangat mungkin diadopsi dari apa yang dilihat di sekitarnya. Tak jarang, kecurangan-kecurangan kecil ini lama-kelamaan menjadi sebuah kewajaran yang lazim terjadi sehingga menjadi kebiasaan yang tidak dianggap salah. Sebut saja, kebiasaan mencontek, enggan untuk antri, menyogok oknum polisi saat kena tilang, melakukan suap saat melamar PNS, dan lain sebagainya. Melalui kegiatan sosialisasi ini, mahasiswa semakin menyadari bahwa yang 
dimaksud dengan korupsi bukan hanya tindak pidana yang melibatkan kerugian keuangan negara atau kasus suap hingga trilyunan rupiah, namun kembali kepada definisi korupsi secara harfiah yaitu kebobrokan, kebusukan, perbuatan curang dan sejenisnya. Dimulai dengan pembiasan terhadap kecurangan-kecurangan kecil dalam kejadian sehari-hari, lalu terus dipupuk semakin subur sehingga seorang individu mampu dengan mudahnya melakukan kecurangan besar hingga merugikan negara dan masyarakat. Bermodalkan penerapan nilai-nilai dasar anti korupsi yaitu jujur, peduli, mandiri, disiplin, tanggungjawab, kerja keras, sederhana, berani dan adil, maka diharapkan kebiasaankebiasaan yang dapat melahirkan perilaku koruptif dapat ditekan semaksimal mungkin agar korupsi sekecil bentuknya apapun dalam dicegah.

Sosialisasi anti korupsi yang dilakukan di Fakultas Teknik Universitas Muhammadiyah Jakarta disambut baik oleh pimpinan dan tentunya oleh para mahasiswa peserta sosialisasi. Kegiatan berlangsung serius namun santai dimana metode pembelajaran yang diterapkan lebih dominan pada aktifitas peserta. Kegiatan role play sangat disukai oleh mahasiswa karena mereka diberikan kesempatan untuk mengaktualisasikan materi yang didapat dan diberi kebebasan untuk mengasah kreatifitas dalam menyusun naskah role play hingga pelaksanaannya di depan kelas.

Kegiatan ini mendapatkan respon yang positif dari para peserta, terlihat dari antusiasme saat sesi diskusi dan sesi kelompok. Saran untuk pelaksaan sosialisasi berikutnya, agar dapat menerapkan metode pembelajaran yang lebih variatif dan menyenangkan, misalnya dengan menggunakan board game anti korupsi dari KPK, melakukan evaluasi berbasis quiz online, atau membuat film singkat tentang anti korupsi sebagai tugas paska sosialisasi untuk diunggah ke media sosial. Hal ini mengingat mahasiswa zaman sekarang yang sangat akrab dengan teknologi informasi.

\section{Daftar Rujukan}

Brataningrum, N. P., Novianto, V., \& Sarjana, P. (2018). Pengembangan Desain Pembelajaran Model Role-Playing Pada
Kompetensi Dasar Mempraktikkan Siklus Akuntansi Perusahaan Jasa Untuk Meningkatkan Pemahaman Dan Integritas Diri Siswa Kelas XII SMA Jurusan IPS

Indonesia, P. R. (2001). Undang-Undang Republik Indonesia Nomor 20 Tahun 2001 Tentang Perubahan Atas UndangUndang Nomor 31 Tahun 1999 Tentang Pemberantasan Tindak Pidana Korupsi.

Kadir, Y. J. G. L. R. (2018). Kebijakan pendidikan anti korupsi di perguruan tinggi. 1(1), 25-38.

Korupsi, T. P. B. P. A. J. J. K. P. d. K. R. D. J. P. T. B. H. K. (2011). Pendidikan Anti Korupsi untuk Perguruan Tinggi.

Kristiono, N. J. H. S. I.-I. S. d. K. (2018). Penanaman karakter anti korupsi melalui mata kuliah pendidikan anti korupsi bagi mahasiswa fakultas ilmu sosial Universitas Negeri Semarang. 2(2), 51-56.

Muchtar, D., \& Suryani, A. J. E. J. P. (2019). Pendidikan Karakter Menurut Kemendikbud. 3(2), 50-57.

Nazifah, L. J. M. J. I. A. (2019). Strategy To Respond Gratification By Identifying Gift-Giving To Government Employee. 1(2), 47-58.

Sugono, D. J. J. P. B. D. P. N. (2008). Kamus besar bahasa Indonesia.

Sumaryati, S. (2015). Implementasi Nilai-Nilai Pendidikan Anti Korupsi Untuk Mewujudkan Karakter Jupe Mandi Tangse Kebedil (Survey Dalam Proses Pembelajaran di SMA Negeri 3 Bantul Pada Tahun Pelajaran 2012/2013).

Supardi, E. J. B. D. P. N. (2004). Kiat Mengembangkan Sikap Mandiri.

Suryani, I. J. d. J. V. K. (2015). Penanaman nilai-nilai anti korupsi di lembaga pendidikan perguruan tinggi sebagai upaya preventif pencegahan korupsi. 14(02), 285-301.

Taja, N., \& Aziz, H. J. J. P. A. I. (2016). Mengintegrasikan nilai-nilai anti korupsi dalam pembelajaran pendidikan agama Islam di sekolah menengah atas. 13(1), 39-52. 